\title{
Radical Democratic Theatre
}

The aim of this article is to interrogate the emergence of a form of participatory theatre that I shall call 'radical democratic theatre'. The term 'radical democracy' derives in the first instance from the political theory of Ernesto Laclau and Chantal Mouffe, but in terms of its application to theatre and performance practices, it might well be drawn in relation to Augusto Boal's Theatre of the Oppressed. Consequently, one useful starting point in grasping what is at stake when speaking of a radical democratic theatre is to trace the limits of Boalian thought by revisiting some of the theoretical assumptions upon which it stands. Two fundamental assumptions of specific concern have to do with (1) the nature of the theatre 'subject', as conceived by Boal, and (2) its relation to the political task of emancipation. Boal expresses this task in the following terms: 'In order to understand the poetics of the oppressed one must keep in mind its main objective: to change the people - "spectators," passive beings in the theatrical phenomenon - into subjects, into actors, transformers of the dramatic action' (Boal, 2000: 122). To begin to approach the limits of this task, and probe what is implicated in its basic presuppositions, I want to focus on what will emerge as a significant theoretical difference over the way in which we might understand the nature and ambition of the strategy of 'transformation' - specifically, by drawing a distinction between the underlying aims of the Theatre of the Oppressed and the project of radical democratic theatre, as it might be conceived today. While Boal thinks the emancipatory potential of theatre predominantly in terms of freedom from oppression, by contrast, I will argue that the fundamental strategic aim of radical democratic theatre is not 'liberation' per se, but the destabilisation of the relational space in which 
political identities are first configured. Radical democratic theatre cannot 'liberate' anyone but it can destabilise the matrices of a given political distribution and in particular release thereby what politics has suppressed first, antagonism and dissent, and second, forms of reciprocal action and empathic identification on which new forms of sociality might be based. The shift in perspective marked here can be thought as a move away from the classical focus of the left on emancipation from oppression to the problem of what Iris Marion Young calls 'domination', which suppresses, not freedom, but rather equality at the level of political engagement. Domination, she tells us, 'consists in institutional conditions which inhibit or prevent people from participating in determining their actions or the conditions of their actions' (Young, 1990: 38).

Placing the emphasis on equality, rather than freedom, by no means entails the denial of oppression. Rather, it signals the attempt to think emancipation beyond the classical rhetoric of revolutionary praxis. I will describe the possibility for this kind of strategic intervention, with reference to Michel Foucault, as necessitating, instead, the practice of the arraignment of power. It is this kind of idea that Randy Martin has in mind when, defending Boal's legislative theatre from its critics, he describes how Boal was able to awaken a recalcitrant public to a consciousness of itself as the primal scene of the political, in which the 'law can be interrupted, reversed, challenged' (Martin 2006: 28). It is also, however, precisely here, where oppositional politics encounters the law, that the limits of this form of participatory theatre are disclosed. This is because it is precisely at the point where opposition moves from resistance to direct engagement with the structures and institutions of power that the democratic moment is most at risk of assimilation and co-option by the forces of the status quo. The 
reasons for this are complex and unnerving - as Laclau and Mouffe have demonstrated through their astute critique of 20th century Marxism: '[there is] no subject' they write, 'which is absolutely radical and irrecuperable by the dominant order, and which constitutes an absolutely guaranteed point of departure for a total transformation' (Laclau and Mouffe 2001: 169). I shall call this profound instability, which is constitutive of political identities, the 'democratic limitation'. The democratic limitation refers to both the inherent volatility of political identities and to the impossibility of reconciling those social antagonisms, constitutive of the political field, according to a universal political settlement. Through this concept we will be able to discern, not just what makes radical democratic theatre and performance possible; we will also be able to specify in what sense it can be called radical insofar as it reveals the precariousness of every essentialist political discourse.

\section{Radical Democracy}

To begin to understand what is so radical about democracy, I'd like to consider for a moment a controversial hypothesis. Radical democracy is a promissory note born with the democratic concept of politics but immediately suppressed in practice. This means, what passes for democratic politics today is simply the name designating a contemporary form of 'antipolitics' insofar as the governmental operation of 'participation-throughrepresentation' consists in the organisation of the people around its fundamental exclusion from power. Democracy in representing the people represents the de facto suppression of the democratic impetus. This paradox of democratic politics is never far from view: politicians - the first to advocate the merits of democracy - as soon as they act, do so (to borrow a locution from Marx) as its undertakers. ${ }^{i}$ Still, if democratic politics as a political 
formation remains questionable today, this is not to say that the democratic impetus does not make its presence felt: here we are not speaking of the politics of political parties, but the politics of irruption - a politics of selfdetermination wherein a 'demos' - a people - constitutes itself, however momentarily and partially.

To grasp the significance of the concept of self-constitution it is important to distinguish between the articulation of the figure of the demos as the object of political discourse, and its 'self-articulation': between its nominalisation and its self-actualisation. What is at issue here is not simply the plural nature of democratic politics - participation in the contemporary res publica of various different constituencies, whose competing interests are regulated and administered via the electoral system - but rather what that participation implies when viewed outside of such a system: the militant emergence of 'active citizenship' as Étienne Balibar, usefully defines it - in which 'citizenship is not primarily granted or conceded from above but [is] constructed from below' (Balibar, 2004: 48). Consider a brief example, taken from Peru - a protest initiated by the activities in the year 2000 of a group of writers and artists called the Colectivo Sociedad Civil. Here we see radical democracy emerge in the form of an aesthetic practice which was able to stage the 'de-structuring' of the demos as articulated within the totalizing discourses of the political executive. Emblematic of this de-structuring or 'dissent' was Lava la bandera which began with the symbolic act of washing the Peruvian flag at the colonial fountain in the main square of Lima. [PHOTO INSERT]. Writing after the event, Gustavo Buntinx, one of its instigators, described the action as a 'participatory ritual of national cleansing' directed against the corrupt and increasingly despotic regime of Fujimori-Montesinos. Most instructive of all in this example is the way in 
which the demos actualised itself through the spontaneous appropriation of the CSC initiative. Entirely independent of the original act, a series of copycat actions quickly spread the protest from city to city, engulfing, eventually, the whole of Peru. Buntinx is quite right to speak here of 'a system of collective identification' through which emerged 'a citizenry in the process of formation' (Buntinx 2005: 46). However, a process of formation is more than an act of identification around the speculative positivity of a collective signifier; it is also an act of dis-articulation, whereby a discourse which constitutes the people as the passive object of political power suffers a radical loss of legitimacy. What Lava la bandera reveals is that it is not, and never has been, in the power of governments to decide on the proper meaning of the 'name of the people'. On the contrary, the name of the people always bears within it an undisclosed remainder, irreducible to the discursive regime of the prevailing hegemonic order. This 'democratic excess', as Jacques Rancière calls it, is nothing less than 'the impurity of politics, the challenging of governments' claims to embody the sole principle of public life' (Rancière 2006: 62). Lava la bandera attests to this sudden and unanticipated reversal of the people from the condition of passivity to activity; but more fundamentally, it reveals the democratic impetus, in its full radicality, as a power of dissent. In this sense the radicality of radical democracy derives not so much from the independence as from the constitutive exteriority of the demos with respect to the governmental exercise of power. The power of radical democracy lies in the exteriority of its forms. It is not then because the demos is excluded from political power albeit that it often is - but because it can never be fully included that it retains within itself and reserves for itself the power of opposing a polity that claims to incarnate its 'will'. 


\section{The Demos and Boal's Concept of Theatre}

There is, for sure, a great deal of commonality between the Theatre of the Oppressed and radical democracy thus described. Boal himself tells us: The Theatre of the Oppressed has as its first premise, the intention to democratise the stage space' (Boal 1998: 67). In his book Legislative Theatre, Boal attempts to bind participatory politics and theatre to a common destiny. To do this Boal draws upon two founding parables - that of democratic politics and that of the birth of classical theatre - in order to elicit from them a proposition which will capture the very essence of a democratic theatre: the positing of the essential equality of actor and spectator within the theatrical event (Boal 1998: 61). According to the first narrative, we discover a fundamental contradiction at the origin of politics, constitutive of the very place of the people. It is politics that constitutes the $\underline{\text { demos }}$ as both the inert object of political power and as its legitimating source. On the one hand, the "polis comprised the entirety of people who had no power at their disposal' (Boal 1998: 20) thus '[p]olis came to be the power of the powerless' (Boal 1998: 21). On the other hand, the polis gives rise to the problem of citizenship, which requires the political organisation of a people under the sign of equality. The Greek solution to this dilemma is wellknown: they restricted the entitlement of citizenship to the few - the 'fasces, the small bundle of sticks' (Boal 1998: 21). It is consequently in the figure of the demos that, for Boal, we find the very image of the oppressed as well as the dissipated image of democratic politics. The second story by contrast serves to connect theatre to politics through the power of theatre to give voice to the act of dissent. This is captured in the tale of Thespis who, breaking ranks with the chorus, enraged the magistrate Solon by speaking 
his mind on issues of political and civic life. When Solon, after the play had ended, accused Thespis of subversion, the wily trickster cunningly replied that it was not he who spoke but his character (Boal 2006: 65). In that moment, theatre as we know it, at least in Boal's relating of the tale, was born with an act of sedition.

Nevertheless, a problem emerges when we try to align the aims of a theatre of the oppressed with those of radical democracy. To begin to understand the nature of this difficulty we need to return to the canonical form in which this theatre of liberation first comes to expression. Boal's position, although it most certainly changed over the years, might nevertheless be summarised according to two founding moments. The situation of the demos is defined by a specific kind of oppressive reality - a reality established on the basis of a relation of oppressors and oppressed. Typically, reality refers to a structure where, on the one hand, we can identify the dominant, exploitative and, in short, 'ruling class', and on the other hand, the people who suffer the expropriation of their labour, the exploited. Let me call this relation the 'oppressive relation' which can be approximated to the following interpretation of reality: wherever oppression and its immiserating effects can be found we also see a strict univocal relation in operation, establishing and fixing the identity of oppressor and oppressed. The 'oppressive relation' is thus the first moment in the Boalian schema. In order to divulge the second moment, however, we need to remind ourselves that for Boal the theatre, in the hands of the ruling class, is a tool of domination'.

In fact the problem is not that theatre exhibits the oppressive relation so much as it constitutes, as Boal says, a 'powerful system of intimidation' (Boal 2000: 46) whose main objective is 'to bridle the individual, to adjust 
him to what pre-exists' (Boal 2000: 47). It is not only ideological manipulation that Boal has in his sights here. More profound than this is Boal's insight that theatre designates a specific structure of domination in which the audience is rendered inert insofar as it is the addressee of the theatre spectacle. This is the second moment in the schema of the Theatre of the Oppressed. It can be defined as follows: a structure of domination is a structure that produces passivity. It is a structure that suppresses the desire of the spectator to transgress the boundary which separates the world of the play from the world to which they have been condemned as if by fate. It corresponds to two distinct and incommensurable realities, dividing those who are entitled to act and make decisions, from those designated the recipients of those actions. In this way, what theatre does is infinitise the distance between the audience and the actor. What the structure of domination denies to us, thereby, is the ability to take possession of that which the actor embodies: what Boal calls the 'protagonic function' (Boal, 2000: 180). Transformed into a mere object, the spectator is deterred from accessing the very language of reality. Hence Boal manages to connect the situation of the theatre (the machine which manufactures passivity) to that of the 'oppressive relation'. In other words, he is able to extend the structure of domination through the metaphor of theatre to all social agents deprived of the protagonic possibility of acting: of participating in the affairs of public life, and thus of changing their world.

It is also due to their close proximity that the structure of domination and the 'oppressive relation' can be correlated in a practical critique of the conditions of spectatorship. If the structural passivity of the audience is to be overcome it is precisely because the audience represent nothing less than the oppressed themselves, the people, the dispossessed demos. And that 
means: in order to break the barrier that separates the audience from the actors - in order for theatre to become a 'weapon for liberation' (Boal 2000: ix) - a 'theatre of the oppressed' must of necessity invert the structure of domination which is the condition of theatre itself. The propaedeutic purpose to which Boal assigns his theatre could not be clearer: if theatre speaks the language of reality then a theatre of the oppressed must train the audience in that 'protagonistic' language. Thus, when Boal speaks of 'rehearsing the revolution', the word rehearsal does not signify an operation that would entail the constant deferral of real efficacy: on the contrary. This is precisely what is at stake with the hypothesis of metaxis - the simultaneous occupation by the spect-actor of 'two worlds, that of reality and that of the representation of this reality which is [his]' (Boal 2006: 74). For Boal, the verb to rehearse, grasped in terms of the metaxis, becomes synonymous with the verbs to do and to be: "The rehearsal of an action is itself an action, the practice of an action then to be practiced in real life' (Boal 2004: 72). To enter 'metaxic space' is not principally, as it is for Warren Linds, to enter a liminal and ungrounded space of play; nor is it simply a means of 'developing an awareness of the space in which we work and interact' (Linds 2006: 117). For Boal, it is to engage in an act of radical regrounding. Boalian rehearsal signifies a practice whose aim is the revolutionary transformation of the very condition of the theatre, which 'democratises' it by overturning its structure of domination. Overturning the structure of domination opens the way for a 'pedagogy of the act', and already, in effect, provides a means of transforming reality itself and thus the 'oppressive relation' into a 'non-oppressive relation'. Boal expresses the idea, at one point, in an extraordinarily arresting pronouncement: 'All 
spectators [are] equally free to experience the liberating seizure of speech' (Boal 2006: 74).

However, before we get carried away by the idea of the liberating seizure of speech', I would like to raise several objections over Boal's accounting of reality. We are obliged to ask, at the very least, whether or not there is a danger here, that in the transitive passage described by the metaxis we have only moved from the action of fiction to the fiction of action. Why should we assume that an oppression rehearsed and reversed (on stage) would lead to an actual transformation of the oppressed at the level of reality? One way to answer this affirmatively would be to embrace a literalist concept of representation according to which one could then posit a transparent relation between a representation and its signified. Thus a passage could be established verbatim between two orders of reality: the order of the stage and the image, and the order of the world and the real. And indeed that is what Boal's notion of 'transubstantiation' through metaxis assumes. But this provokes two worries, in my view. First, the assertion of the straightforward correlation of the 'real of the image' and the 'image of the real' overlooks a high degree of opaqueness in the structure of representation. It is not enough, in other words, to suggest reality answers to its image, as though one could peer through the latter in order to disclose the laws of the former. It is well known that representation is not a 'transparent medium' through which meanings are effortlessly transmitted $\underline{\text { literartim, }}$ and if it were, it could not be a representation (see Laclau 2007: 98). The medium of representation is not the real but the symbolic. A further substantive question arises on the back of this concern and has to do with Boal's juxtaposition of the structure of domination, the structure which produces passivity and inequality, and the oppressive relation, in which free 
subjectivity is curtailed. It is by overturning the structure of domination that the Theatre of the Oppressed provides the subject with a means to liberate themselves from the oppressive relation by engaging in a critical appropriation of that image of reality. But in order to understand what limits, if any, we should set on this act of emancipation we need to examine whether oppression, thus described, that is, as an oppressive relation, is really adequate to the reality it is meant to structure; or whether, instead, the kind of relation identified here is itself founded on a more complex set of operations, which are not only more difficult to discern, but infinitely more difficult to transform.

3. Theatre of the Oppressed at the Limits of Political Subjectivity The first assumption to be challenged is that of the oppressive relation itself. Rather than conceiving oppression as presenting itself in the register of a 'literalist' logic, the task here is to see the 'oppressive relation' as already shot through with an opacity that undercuts the form of rationality demanded by the discourse of classical emancipation, upon which the rhetoric of transformation relies. Laclau explains the opacity usefully in terms of Derrida's concept of undecidability: 'the identity of the oppressive forces,' he writes, 'has to be in some way inscribed in the identity searching for emancipation. This contradictory situation is expressed in the undecidability between internality and externality of the oppressor in relation to the oppressed' (Laclau 2007: 17). Here we confront a choice: either, we see the dichotomy separating the oppressed from the oppressor as hypostatizing the oppressive relation, resulting in the fixation of social agents in an intransigent struggle. This would see a pathological closure of the identity of each agential term around its fundamental impossibility, 
encapsulated by the inassimilable presence of the other, since all acts of self-identification are constructed through an inverse reciprocity in which self-identification requires its excluded term. Or, we can conceive an alternative way of thinking the oppressive relation which takes account of the ambiguity constitutive of social antagonisms. What results in this case is a rejection of any talk of the radical overcoming of antagonism, i.e., the elimination of alterity from the social field, since antagonism on this view is accepted as constitutive of every identity. Accordingly, the struggle shifts elsewhere, as Laclau puts it, to the constant renegotiation of the forms of [the other's] presence' (Laclau 2007: 30).

No doubt it could be objected that Boal conceives the 'oppressive relation' in rather more complex terms than those that I have ascribed to him. One might point to Boal's later therapeutic techniques, as Mady Shutzman has done, which 'address themselves to the internalized struggle between the interdependent oppressed and oppressor within each individual' (Shutzman 2004: 141). Hence it could be argued that Boal acknowledges the process whereby we assimilate the identity of the oppressor to ourselves. Boal's notion of 'cop in the head' would seem, at least, to recognize a certain complexity in the dimension of the subjectivity of the oppressed. Otherwise stated, for Boal, situations of oppression are also situations of repression not in the sense of physical force, but in the psychoanalytic sense of an unconscious operation, a psychic repression. With this, the oppressive relation is not obviated, but internalised by the everyday evasions we ourselves practice. This brings us, however, to assumption number two: namely, to the idea that practices of everyday repression not only institute but serve to conceal oppression at the level of a suppressed reality, namely, through the perpetration of some kind of ideological deception which can be 
psychoanalysed as misrecognition. When Boal says, for instance: 'if an internal oppression exists, it is because it comes from some barracks or other, exterior to the subjectivity of the subject' (Boal 2006: 6), he is also implicitly endorsing a concept of identity that is ultimately recuperable, as though subjectivity in the final instance existed prior to the processes of domination through which it is formed. Against this idea, which conflates the theory of ideology with that of the unconscious, we need to challenge the proposition that it is merely a matter of exposing oppression by breaking through the tactics (psychic or otherwise) of repressive agents (ourselves included), whose function is precisely to repress knowledge of this reality so as to stupefy us into tolerating oppression. As Slavoj Žižek has shown, ideology is misconstrued when considered a falsification of a 'real' reality which gets suppressed (Žižek 2008: 45); on the contrary, reality, as Freud himself asserted through the 'reality principle', is precisely a positivity that I embrace in the forms of self-identification through which my social being becomes a positivity for me. Psychoanalytically grasped, reality does not correspond to something unconscious, something suppressed, but to a state of wakefulness.

Consequently, overcoming ideological misrecognition cannot simply be a matter of modifying the behaviour of domesticated subjects. Indeed, such an analysis of the oppressions that we identify demonstrate that it is not a question of transforming subjects and their reality, but rather of confronting the symbolic network constitutive of social reality and its processes. It is through these structures that political identities and subjectivities are constructed. This means, we would have to confront not simply the oppressive relation and its ideological repression, but the rather more complex processes of subjectification and ideological inscription through 
which the 'oppressive relation' produces subjects. The shift in perspective which this requires, as we shall now see, corresponds to what I earlier described as a shift from the problem of emancipation - the classical problem of freedom - to that of domination - the contemporary problem of inequality. Here, the structure of domination is not, as it was for Boal, a means of 'adjusting' the subject to the condition of his or her oppression. Nor is it about a lack of individual freedom. Rather, it specifies that the very condition of the subject is domination itself.

To say that the structure of domination produces subjective passivity is to say that it prohibits and deters the democratic impetus from coming to expression; it suppresses the desire for any active participation in determining the collective conditions of one's social existence. One could press this idea further and go so far as to say in a modern disciplinary society such as ours, the structure of domination disposes of any need for an oppressive relation. This leads to Foucault's famous remark in Discipline and Punish, the 'perfection of power should tend to render its actual exercise unnecessary' (Foucault 1991: 201). In other words: if as we have said the condition of the subject is domination itself, then that is because domination produces its effects through complex processes of subjectification. On the other hand, here we also reach a conceptual limit, which forces us to reconsider the totalising effects of the structure of domination construed as a process of subjectification via Foucault. If domination really is all pervasive - if the subject is merely an effect of social relations, which 'predetermine' the perceptible forms through which it is manifested, then there can be no non-mediated perspective available to the subject whereby the social relations in which they feature could be rendered visible as a whole in their immediacy, since that would mean the subject could break free of the very 
constraints that make social existence intelligible. But it then becomes almost inconceivable how one would be able to break out of the "circle of oppression', which operates on subjects. Correlatively, it becomes almost impossible to see how, pursuing this logic, Foucault could avoid totalising the apparatus of inegalitarian power. So how does this way of reconceptualising the structure of domination help us understand the strategic possibilities of radical democratic theatre and performance? In fact the resources for answering this question can already be found in Foucault: 'there are no relations of power without resistances; the latter are all the more real and effective because they are formed right at the point where relations of power are exercised' (Foucault 1980: 142).

In Foucault's analysis of power, two principal operations are discernible: one represents the procedural application of power; the other endeavours to legitimate those practices. Power acquires its legitimacy by operating in the name of knowledge whose warrant is 'truth'. Acquiescing to such truths, we acquiesce to the power of knowledge. In this way, we also inevitably consent, as Foucault reminds us, 'to [those actual] effects of power which [truth] induces' (Foucault 2000: 132) - that is, we acquiesce to procedures of normalisation productive of subjects. This is why, in order to break with, or at least slacken the grip of a specific structure of domination, one must be able to bring the framework of knowledge on which it rests into question: 'It's not a matter of emancipating truth from every system of power (which would be a chimera, for truth is already power) but of detaching the power of truth from the forms of hegemony, social, economic, and cultural, within which it operates at the present time' (Foucault 2000: 133). The question remains, however: how, given the ubiquity and pervasiveness of power, in Foucault's account, can we speak intelligibly of reversing a 
procedure of normalisation and thus envisage a process in which a delegitimation of a particular regime of truth would be possible? The answer can only be that the totalising effects of power are entirely contingent. In other words, while power is necessarily present in every social relation, it is never entirely reducible to those relations, i.e., its form of appearance is incapable of resolving itself into a fully constituted totality. Otherwise put, the processes of subjectification never result in the full determination of the subject and the absolute fixation of the identity of social agents.

The significance of this point can be clarified more precisely once we align it with a second move, using Laclau and Mouffe's appropriation of Althusser's notion of overdetermination - the claim, in their words, that: 'Society and social agents lack any essence, and their regularities merely consist of the relative and precarious forms of fixation which accompany the establishment of a certain order' (Laclau and Mouffe 2001: 98). The overdetermination of the subject means that the 'category of subject is penetrated by the same ambiguous, incomplete and polysemical character which overdetermination assigns to every discursive identity' (Laclau and Mouffe 2001: 121). It is because of this constitutive openness of identity what I earlier called the 'democratic limitation' - that a structure of domination is always in principle reversible. Just as, correspondingly, it is due to the irreducibility of power to the facticity of its forms that we can speak of the possibility of its redistribution and thus of the possibility of detaching it from a given discursive regime of truth. Taken together, what this amounts to is nothing less than the practice of which we spoke earlier, through which the democratic impetus is revealed as the power of the demos to de-structure its formal nominalisation, thus enabling it to break with a given political conjuncture. 
4. The Strategic Aims of Radical Democratic Theatre

Let us see, now, how we can apply this analysis in order to better articulate the strategic aims of radical democratic theatre and performance. To begin with it should be said that there is nothing essentially democratic about the theatre. Given this, it would be absurd to suppose that the strategic aim of radical democratic theatre is the redemption of the Theatre - its reenchantment, so to speak, brought about by the retrieval of what would in effect be its suppressed 'truth': that the theatre constitutes the proper site of (as Nancy has called it) the 'inoperative assembly'. The argument for a radical democratic theatre does not pose as an essentialist discourse on the nature of theatre: it does not say that theatre is political, and it claims no special privilege for theatre as the 'medium of the people'. Radical democratic theatre is perfectly consistent with Rancière's refusal of the 'presupposition that the theatre is communitarian in and of itself' or that its aim should be the emancipation of the spectator (Rancière, 2009: 16). What is at stake here is by no means the political status of theatre or its audience, but rather the political status - or lack thereof - of those who participate in radical democratic theatre and performance projects - a mode of political intervention which proceeds by means of theatre- and performance-making practices and through which a certain kind of political activity becomes enabled, namely, democratic participation. The strategic aim of radical democratic theatre, wherever one finds it, is the promotion and activation of democratic politics. Its task - to borrow from Chantal Mouffe - is to '[deepen and extend] the range of democratic practices through the creation of new subject positions within a democratic matrix' (Mouffe 1993: 57). 
On the other hand, by asserting that there can be no political essence associated with the theatre, either democratic or otherwise, one should perhaps also point out that according to the principle of the democratic limitation, there is equally no essence underpinning communitarian politics. If the thesis of the democratic limitation holds, community - the presupposition of a basic but suppressed commonality constitutive of the $\underline{\text { demos }}$ - cannot mean that the hidden truth of democratic action and the ultimate goal of participation is the achievement of the state wherein a community becomes wholly 'what it is'. Democratic action - if it aims at the formation of a collectivist subject - is always tentative, provisional, and contingent. Insofar as the democratic community is radical, it names a problem and not a solution. This is why democratic action, in its radical sense at least, rests on two essentially negative procedures: the delegitimation of the process of subjectification (i.e., the declassification of subjects) - in fact, their uncoupling from the discursive regime of truth according to which they are 'interpellated'. And the re-articulation of those subjects through a counter-hegemonic process in which political power is challenged and redistributed, according to multiple sites of localisation and resistance, and in view of which new subject positions and identities are opened up on the ground. The first destabilises the structures of domination; the second provides the opportunity for new possibilities of political engagement and struggle. It is precisely this dual process that radical democratic theatre and performance projects engage in and why, as I suggested earlier, they should be thought of in terms of the "practice of the arraignment of power'. Arraignment of power is in fact fundamental to the strategic possibility of radical democratic theatre because it is fundamental to radical democratic action. 
Singaporean artist Jay Koh's photographs 'Signals from Burma' (2007-8), taken in and around Rangoon, provide an interesting case in point. At first glance we are confronted with a collection of rather obtuse images featuring apparently random individuals. These anonymous, silhouetted figures are, in fact, united by nothing other than what they are doing: performing a hand signal. Some pose in front of well-known attractions, gesturing as a tourist might. Others gesture more furtively - as in the photograph of the man whose hand, casually resting on the back of his head as he walks down a street, enacts the same peculiar hermetically-sealed gesture of signalling. [INSERT IMAGES] The power and significance of these apparently contingent, indecipherable, barely visible acts, photographed in a manner reminiscent of holiday snaps, is only revealed once one recalls that in a militarised state such as Burma it is the police order that determines and permits the production and dissemination of meaning. In a system where the enunciative function of speech is strictly monitored - restricted to pre-assigned significations - and where no-one has power over their own gestures, these anonymous, silent, barely noticeable performances translate, suddenly, into a forceful poetics of clandestine political engagement and resistance. In this way, through the seemingly inscrutable gestures of ordinary Burmese people, Koh demonstrates that individual expression is always a possibility, no matter how repressive the situation.

If the word 'arraignment', in its most general sense, means 'to call into question', its more familiar and specific juridical usage is equally relevant. When we think of an arraignment in legal terms, we do so in reference to the charge or indictment brought on behalf of a litigant against the defendant in a court of law. Both meanings - to accuse or indict and to call into question - are pertinent to this notion of the practice of the arraignment of power. The 
idea, then, is twofold. Firstly, arraignment involves calling into question the multiple operations of power that constitute the determinate situation of subjection through which subjects are interpellated. It does this by opening up a space in which the authority of a specific power of subjection is effectively suspended. In particular, it calls into question the dissociating strategies of power by opening up what we might call a space of speech. In fact it reopens precisely that interlocutory and participatory space which disciplinary power attempts to seal off, stifle, or even eliminate altogether. A theatre that practices the arraignment of power, then, is by definition a theatre that stages the encounter between subjects and the conditions of their subjection. Specifically, it brings the subject back to a suppressed power of dissent. The second aspect of arraignment, which is implied in the act of calling into question, is indictment: to arraign power is always to indict a determinate situation of subjection. On the one hand, therefore, to arraign is to begin to reconfigure social agency by withdrawing the subject from those techniques of supervision that aim to suppress dissidence, disobedience, and non-compliance; on the other hand, it is to expose the nexus of knowledge and truth - the framework of power itself - to the questionability of its legitimacy.

Here a final example will help elucidate the point, as well as bring us back to the point at which we departed from Boal: the liberatory power of speech. ¡Por Nosostras Mismas! ('By Ourselves’ 1998) was a collaborative project originated by Jesusa Rodriguez, which targeted the glaring inequality, caused by ill-health, illiteracy, gender discrimination and widespread domestic violence, inhibiting the personal, economic, cultural and political development of indigenous female agricultural workers in rural Mexico. What is interesting about ¡Por Nosostras Mismas!, however, and 
what makes it a particularly fitting place to conclude, is precisely the emphasis it places on the suppressed power of speech. The primary goal of the project was, as Javier Cabral Soto explains in the introduction of the book which followed, 'an education of equality in all aspects of life with the aim of reducing the difference between men and women' (Soto 2004: 17). Using group exercises, structured around themes such as woman and her social condition' or 'woman as creator', the participants were able to gather together to share, reflect upon, and collectivise their experiences. Significantly, the project did not articulate itself around an explicitly ideological struggle; nor was it primarily about rehearsing possible solutions to the immense problems confronting these women. Rather, it was fundamentally an educative process, using participatory tactics such as storytelling, mask-making, and music-making in a creative endeavour that would enable the women to experience for themselves what had for so long been denied to them: the active self-assertion of equality and citizenship. The educative method here did not primarily refer to knowledge acquisition; it signified, rather, and more fundamentally, a process of re-subjectification. In $\_$Por Nosostras Mismas!, in other words, what we find is a form of theatre that intervened in a situation of inequality with the strategic intention of transforming the conditions of subjectification. What it 'transformed' was not the oppressive relation per se, but the context according to which the women were denied the power of collective - that is to say, political - speech.

What we can surmise, from this brief example, I think is the following concluding observation: if radical democratic theatre is able to produce political 'effects', it is because it is able to provide the means for the effective suspension of the conditions of operation through which a structure of domination produces $\underline{\text { its }}$ effects. 


\section{BIBLIOGRAPHY}

Balibar, É. [2004) We, The People of Europe? Reflections on Transnational

Citizenship, trans. James Swenson, Princeton: Princeton University Press.

Boal, A. (2006) The Aesthetics of the Oppressed, trans. Adrian Jackson, London: Routledge.

Boal, A. (2000) Theatre of the Oppressed, Pluto Press.

Boal, A. (1998) Legislative Theatre, London: Routledge.

Buntinx, G. (2005) “Where? When? ¿Dónde? ¿Cuándo?” in When Faith Moves Mountains, Madrid: Turner.

Foucault, M. (1991) Discipline and Punish, The Birth of Prison, trans. Alan Sheridan, London: Penguin.

Foucault, M. (2000) Power, Essential works of Foucault 1954-1984, Vol.3, New York: New York Press.

Foucault, M. (1980) Power/Knowledge, Selected Interviews and Other Writings 1972-1977, Harlow: Longman.

Laclau, E. (2007) Emancipation(s), London: Verso. 
Laclau, E and Mouffe, C. (2001) Hegemony and Socialist Strategy, Towards a

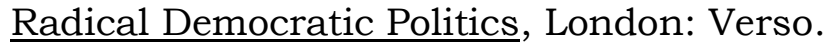

Linds, W. (2006) "Metaxis, Dancing (in) the in-between" in A Boal

Companion, Dialogues on theatre and cultural poltics eds. Jan Cohen-Cruz and Mady Schutzman, New York: Routledge.

Martin, R. (2006) "Staging the Political: Boal and the Horizons of Theatrical

Commitment" in A Boal Companion, Dialogues on Theatre and Cultural

Politics, New York: Routledge.

Mouffe, C. (1993) The Return of the Political, London: Verso.

Rancière, J. (2006) Hatred of Democracy, trans. Steve Corcoran, London: Verso.

Rancière, J. (2009) The Emancipated Spectator, trans. Gregory Elliott, London: Verso.

Shutzman, M. (2004) "Brechtian Shamanism, the political therapy of Augusto Boal" in Playing Boal, Theatre, Therapy, Activism, New York: Routledge.

Soto, J. (2003) ¡Por Nosostras Mismas! Instituto Mexicano del Seguro Social.

Young, M. (1990) Justice and the Politics of Difference, New Jersey: Princeton University Press. 
Žižek, S. (2008) The Sublime Object of Ideology, London: Verso.

i When Tony Blair was asked by the first Chilcott Inquiry to justify his expression of 'no regrets' over the decision to invade Iraq his post hoc appeal was to the legitimacy of a 'just war', self-evidently encapsulated by - or such was his assumption - the proper name 'democracy'. According to Blair's contention, in toppling Saddam, 'the certainty of suppression' had been supplanted by the 'uncertainty of democratic politics' (quoted in The Guardian 30.01.10). 